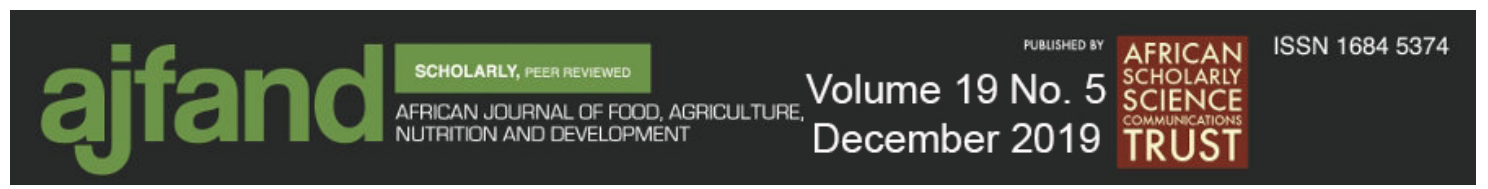

University of Illinois - SIL Farm.Doc Series

Afr. J. Food Agric. Nutr. Dev. 2019; 19(5): 15159-15168 DOI: 10.18697/ajfand.88.SILFarmDoc11

\title{
EVALUATING THE BENEFITS OF IMPLEMENTING SOY-MAIZE CROP ROTATIONS IN SUB-SAHARAN AFRICA
}

\section{Liana Acevedo-Siaca ${ }^{1}$ and Peter Goldsmith ${ }^{2}$}

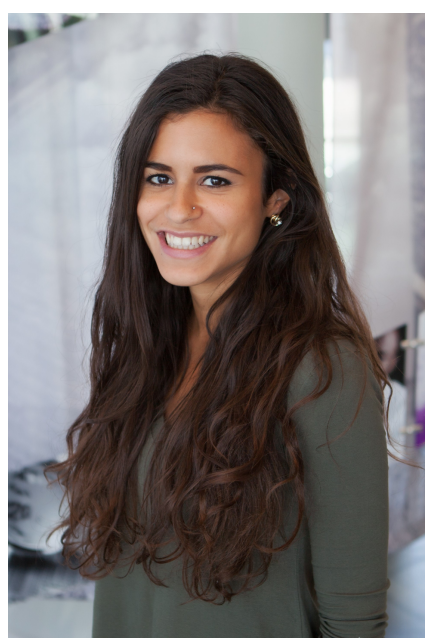

Liana Acevedo-Siaca

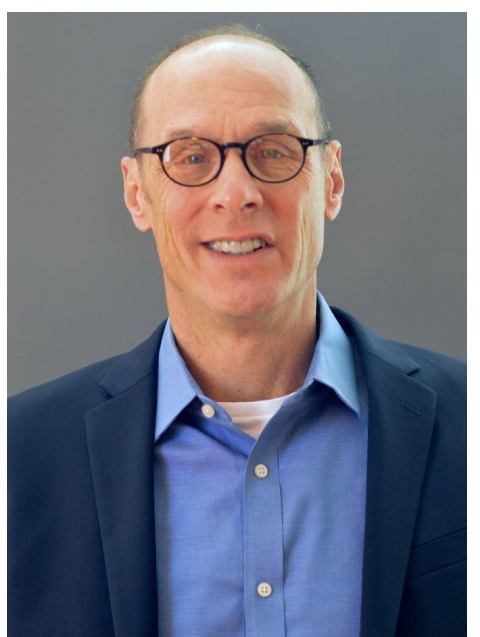

Peter Goldsmith

About the Authors

${ }^{1}$ Liana Acevedo-Siaca is a graduate student researcher with the Department of Crop Sciences at the University of Illinois at Urbana-Champaign Email: acevdsc2@,illinois.edu

${ }^{2}$ Dr. Peter Goldsmith is the Director of the Soybean Innovation Lab and a Professor in the Department of Agricultural and Consumer Economics at the University of Illinois at Urbana-Champaign

Email:pgoldsmi@,illinois.edu 
Maize is one of the most important crops on the African subcontinent, accounting for over half of daily caloric intake in some regions. However, continuous cropping of maize has led to extensive degradation of soil and decreased crop productivity. The cultivation of soybean holds great promise in improving agricultural systems in subSaharan Africa. Introducing soy into rotation with maize is a method to diversify diets and better nutritional status, reduce abiotic and biotic stresses, and improve soil fertility, all the while enhancing crop productivity and generating more income for farmers.

There is great opportunity to improve crop productivity in SSA through the implementation of soy-maize rotations as a form of agricultural intensification. Maize is an important staple crop and is widely cultivated in many regions of SSA (BaduApraku and Fakorede, 2017; Ekpa et al., 2018). The combination of legume and cereal crops creates a stable system that can help protect soil fertility and reduce abiotic and biotic pressures, while also producing high yields (Agyare et al., 2006; Nyagumbo et al., 2016; Franke et al., 2018; Uzoh et al., 2019). Indeed, yields in maize are higher when subsequently planted after soybean when compared to continuous cereal cultivation (Agyare et al., 2006; Nyagumbo et al., 2016; Frank et al., 2018; Uzoh et al., 2019). Additionally, soy-maize rotations have been very successful in other tropical parts of the world, offering great promise to intensify agricultural production in SSA (Oliveira Duarte et al., 2007; Duarte and Kappes, 2015; Goldsmith and Montesdeoca, 2018; Adie and Krisnawati, 2018).

Several agronomic benefits are associated with the use of soy-maize rotations in the tropics, including increased soil fertility, decreased biotic pressure, and increased maize and soy yields (Agyare et al., 2006; Frank et al., 2018; Uzoh et al., 2019). Indeed, soy-maize rotations are a widely accepted system to improve crop productivity, increasing SSA cereal yields by an average of 0.49 tons/hectare or more in fields planted after a legume when compared to cereals in continuous cultivation (Baijukya et al., 2016; One Acre Fund, 2016; Franke et al., 2018).

Soy-maize rotations are widely considered a sustainable method for nutrient management in farming systems, as soy can contribute to the nitrogen economy of the soil (Kohjely et al., 2018; Franke et al., 2018; Uzoh et al., 2019). Soybean provides high-quality residues that are high in nitrogen and have a low carbon to nitrogen ratio. Rotations that include soybean decrease the need for chemical fertilizer inputs by adding available soil nitrogen (between $44-300 \mathrm{~kg} \mathrm{H}$ ha-1/year) while sometimes making less-labile forms of phosphorus more accessible to cereal crops (Khojely et al., 2018; Richardson et al., 2009).

The additional nitrogen fixed by soybeans has been found to significantly increase maize yields subsequently planted after soy (Franke et al., 2018). These results are also sustainable over long periods of time, indicating the stability of this rotation system (Agyare et al., 2006; Frank et al., 2018). For example, a long-term study in the Guinea Savannah Zone of Northern Ghana found that implementing a soybean-maize rotation helped to sustain higher maize yields over the period of 11 years when 
compared to other maize rotation strategies in the same region (Agyare et al., 2006). Furthermore, soybean-maize rotations provide the most total energy value and protein yield produced when compared to other rotation approaches (Agyare et al., 2006; Goldsmith and Montesdeoca, 2018). Finally, it was found that rotating between maize and legumes was more successful at increasing maize yields than traditional intercropping with both crops (Agyare et al., 2006). Additionally, legumes can improve maize's phosphorus acquisition by changing the chemical and biological properties of the soil (Frank et al.,2018).

Utilization of soy-maize rotations presents the opportunity for farmers to diversify their agricultural production systems and build resilience against devastating biotic factors. One of the largest threats to maize production in SSA is Striga (Striga hermonthica), a parasitic weed that can cause yield losses in maize of up to $80 \%$ (Kim et al., 2002; Kanampiu, 2018). Consequently, Striga is the most important species affecting cereal production in sub- Saharan Africa and has been credited to producing \$7 billion USD in losses (Gethi et al., 2005; Kim et al., 2002). However, soybean does not act as a host for Striga and can help to reduce the prevalence of the parasitic weed. Soybeans exudate strigolactones from their roots, which induce the germination of Striga seeds (Bouwmeester et al., 2007, Odhiambo et al., 2011). This induction of suicidal germination by soybean can aid in drastically decreasing Striga weed seedbanks in the soil, consequently reducing weed pressure in later maize rotations and increasing yields (Carsky et al., 2000; Frank et al., 2018). One study found that maize yields increased by $90 \%$ when planted after a soybean rotation in Striga infested fields (Carsky et al., 2000). Additionally, planting soybean is preferable to leaving fields fallow as may native grasses can act as a host to Striga, increasing Striga seed bank and negatively affecting maize production (Frank et al., 2018).

The ability to reduce pest pressure with soy-maize rotations is less clear with nematodes, stem borers, and the fall armyworm. For example, soybeans are not effective at controlling nematode populations as they can also act as a host, causing buildups of nematode populations in the field. In a study in Cameroon, it was found that stem borer attacks increased in response to soy-maize rotations, likely due to the increased nutritional status of maize due to the soy rotation (Chabi-Olaye et al., 2005; Frank et al., 2018).

Currently, maize yields in SSA are being devastated by the arrival of the fall armyworm. Throughout sub- Saharan Africa estimated maize yield losses to fall armyworm range from $20-50 \%$ and cost up to $\$ 6.2$ billion USD annually (FAO, 2018, Early et al., 2018). Although fall armyworm can affect soybean, it typically acts as a secondary pest, preferring C4 grasses (Sosa-Gomez et al., 2017; Hardke et al., 2015). Yet, soybean can become completely defoliated by fall armyworms in circumstances where severe infestations of a typical host, such as maize, precedes the planting of soy (Sosa-Gomez et al., 2017). At the moment, little information is available about whether the inclusion of a soy rotation would help to diminish pressure from fall armyworm in SSA. 
Continuous maize cultivation is believed to fuel a lack of diet diversity throughout SSA (Mango et al., 2017). Correspondingly, many studies and policy recommendations have called for increased diet diversification in SSA, beginning with diversifying agricultural production (Mango et al., 2017). Crop diversification is known to play an essential role in improving household food and nutritional security (Mango et al., 2017). Soybean is a good source of protein, which can supplement a carbohydrate-heavy diet and provide essential amino acids not found in maize (OECD/FAO 2016).

To effectively implement soy-maize rotations, it is important to acknowledge the tremendous amount of diversity present economically, politically, culturally, and ecologically in SSA. Soil types, rainfall, and climate patterns all vary greatly both within countries and across the entire continent affecting how soy-maize rotation can be applied. Sometimes these factors can act as an inhibitor or limitation to the adoption of new agricultural techniques and technologies (OECD/FAO, 2016). Consequently, there is no one singular way to increase agricultural intensification through soy-maize rotations and approaches need to be tailored to the needs of specific regions. Additionally, many of the limitations that affect soy-maize rotation efficacy are the same issues that generally affect agricultural production in SSA such as poor infrastructure, inadequate farmer extension services, limited access to agricultural resources and inputs, limited access to markets, climate change, and political instability or civil strife (Byamugisha, 2013; OECD/FAO, 2016; Tadele, 2017).

Finally, one of the biggest inhibitors to the adoption of soy-maize adoption is the initial lack of access to agricultural inputs (ex. high-quality seeds, fertilizers, and pesticides) and extension services. Accessing agricultural resources has been a persistent problem to smallholder farmers in SSA (Tadele, 2017; Goldsmith, 2018). While soy-maize rotations should reduce the need for some inputs, such as fertilizer or herbicides, and raise income through the production of higher yields, there may still be issues with farmers accessing agricultural services that could improve productivity.

\section{References}

Abera, K., O. Crespo, J, Seid, F. Mequanent. (2018) "Simulating the impact of climate change on maize production in Ethiopia, East Africa." Environmental Systems Research, 7, 4 .

Adhikari, U., A.P. Nejadhashemi, S.A. Woznicki. (2015) "Climate change and eastern Africa: a review of impact on major crops." Food and Energy Security, 4, 110-132.

Adie, M.M., and A. Krisnawati. (2018) "Identification of soybean genotypes adaptive to tropical area and suitable for industry." Earth and Environmental Science, 102, 012045 . 


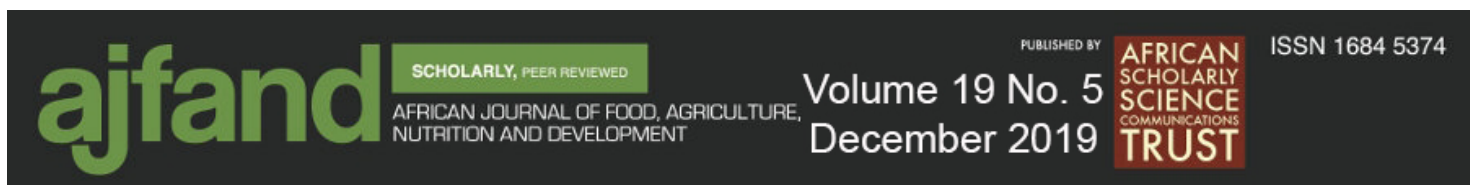

University of Illinois - SIL Farm.Doc Series

Agyare, W.A., V.A. Clottey, H. Mercer-Quashire, J.M. Kombiok (2006) "Maize Yield Response in a Long-term Rotation and Intercropping Systems in the Guinea Savannah Zone of Northern Ghana.” Journal of Agronomy, 5, 232-238.

Amare, M., Cissé, J.D., Jensen, N.D. dan Shiferaw B. "The Impact of Agricultural Productivity on Welfare Growth of Farm Households in Nigeria: A Panel Data Analysis.” FAO. Rome. 2017. Web.

Andersson, M.S., A. Saltzman, P.S. Virk, W.H. Pfeiffer. (2017) "Progress update: crop development of biofortified staple food crops under HarvestPlus." African Journal of Food, Agriculture, Nutrition, and Development, 17, 11905-11935.

Badu-Apraku, B. and M.A.B. Fakorede. (2017) "Maize in Sub-Saharan Africa: Importance and Production Constraints." Advances in Genetic Enhancement of Early and Extra-Early Maize for Sub-Saharan Africa. Springer International Publishing.

Baijukya, F., L. Wairegi, K. Giller, S. Zingore, R. Chikowo, P. Mapfumo. (2016) Maize-legume cropping guide. Africa Soil Health Consortium, Nairobi.

Barnabás, B. K. Jäger, A. Fehér. (2007) "The effect of drought and heat stress on reproductive processes in cereals." Plant, Cell, and Environment, 31, 11-38.

Bouwmeester, H.J., C. Roux, J.A. Lopez-Raez, G. Becard. (2007) "Rhizosphere communication of plants, parasitic plants and AM fungi." Trends in Plant Science, 12, 224-230.

Buisman, L.R., E. Van de Poel, O. O’Donnell, E.KA. van Doorslaer. (2019) "What explains the fall in child stunting in Sub-Saharan Africa?" SSM-Population Health, 8,100384 .

Byamugisha, F.F.K. (2013) Securing Africa's Land for Shared Prosperity: A Program to Scale Up Reforms and Investments. International Bank for Reconstruction and Development, The World Bank. Washington DC.

Carsky, R.J., D.K. Berner, B.D. Oyewole, K. Dashiell, S. Schulz. (2000) "Reduction of Striga hermonthica parasitism on maize using soybean rotation." International Journal of Pest Management, 46, 115-120.

Chabi-Olaye, A., C. Nolte, F. Schulthess, C. Borgemeister. (2005) "Effects of grain legumes and cover crops on maize yield and plant damage by Busseola fusca (Fuller) (Lepidoptera: Noctuidae) in the humid forest of southern Cameroon." Agriculture, Ecosystems and Environment, 108, 17-28.

Chianu, J.N., J.N. Chianu, F. Mairura. (2012) "Mineral fertilizers in the farming systems of sub-Saharan Africa. A review" Agronomy for Sustainable Development, 32, 545-566. 


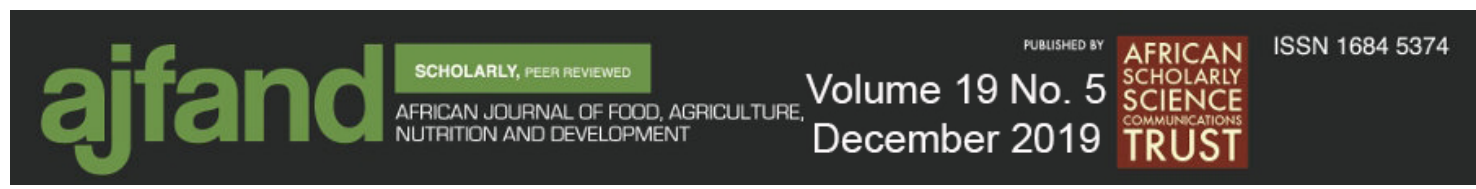

University of Illinois - SIL Farm.Doc Series

D’Souza, A. and D. Joliffe. (2014) "Food Insecurity in Vulnerable Populations: Coping with Food Price Shocks in Afghanistan." American Journal of Agricultural Economics, 96(3), 790-812.

Dale, A., C. Fent, K. Strzepek, M. Lickey, S. Solomon. (2017) "Climate model uncertainty in impact assessments for agriculture: A multi-ensemble case study on maize in sub-Saharan Africa." Earth's Future, 5, 337-353.

Devi, K.N., L.N.K. Singh, T. Sunanda, H. Nanita, B. Singh, K.K. Singh, M.W. Singh. (2012) "Response of Soybean [Glycine max (L.) Merrill] to Sources and Levels of Phosphorus." Journal of Agricultural Science, 4, 44-53.

Dhau, I., E. Adam, O. Mutanga, K.K. Ayisi. (2017) "Detecting the severity of maize streak virus infestations in maize crop using in situ hyperspectral data." Transactions of the Royal Society of South Africa, 73, 8-15.

Dixon J., A. Gulliver, D Gibbon. (2001) Farming systems and poverty: improving farmers' livelihoods in a changing world. FAO and World Bank, Rome and Washington.

Duarte, A. P., and C. Kappes (2015) "Evolução dos sistemas de cultivo de milho no Brasil." Informações Agronômicas, 152, 15-18.

Early, R., P Gonzalez-Moreno, ST Murphy, R Day. "Forecasting the global extent of invasion of the cereal pest Spodoptera frugiperda, the fall armyworm." NeoBiota, 40, 25-20.

Ekpa, O., N. Palacios-Rojas, G. Kruseman, V. Fogliano, A.R. Linnemann. (2018) "SubSaharan African maize-based foods: Technological perspectives to increase the food and nutrition security impacts of maize breeding programmes." Global Food Security, 17, 48-56.

FAO (1997) "Chapter 4 - Food Supply Systems in Africa." Agriculture food and nutrition for Africa - A resource book for teachers of agriculture, Publishing Management Group, FAO Information Division, Rome.

FAO. (2004) "The Role of Soybean in Fighting World Hunger." FAO Commodities and Trade Division, Basic Foodstuffs Service. Web

FAO. "Growing maize and soybean in rotation." FAO. 2010. Web.

FAO. "Fall Armyworm keeps spreading and becomes more destructive." Food and Agriculture Organization, June 28, 2018. Web.

FAO. “Crop Production Data [Maize]” FAO. 2019. Web. 


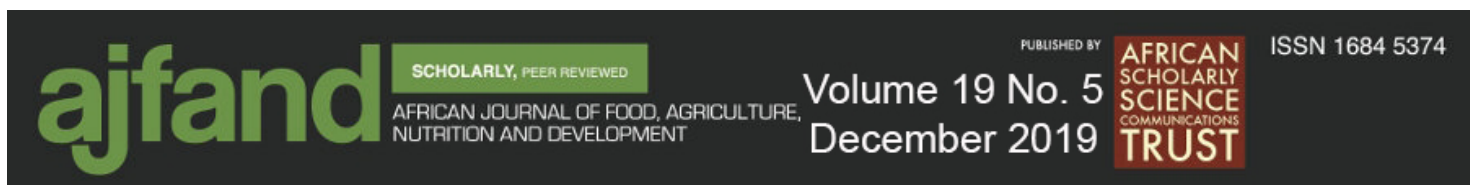

University of Illinois - SIL Farm.Doc Series

FAO. "How to practice integrated pest management?" Food and Agriculture Organization. 2019a. Web.

Franke, AC, G.J. van den Brand, B. Vanlauwe, K.E. Giller (2018) "Sustainable intensification through rotations with grain legumes in Sub-Saharan Africa: A review." Agriculture, Ecosystems and Environment, 261, 172-185.

Foyer, C. H., K.H.M. Siddique, A.P.K. Tai, S. Anders, N. Fodor, F. Wong, N. Ludidi, M.A. Chapman, B.J. Ferguson,

M.J. Considine, F. Zabel, P.V.V Prasad, R.K. Varshney, H.T. Nguyen, H. Lam (2018) "Modelling predicts that soybean is poised to dominate crop production across Africa." Plant, Cell and Environment, 42, 373-385.

Galasso, E. and A. Wagstaff "Economic Costs of Stunting and How to Reduce Them." World Bank Group Policy Research Note. September 22, 2016. Web.

Gethi, J.G., E.E. Smith, S.E. Mitchell, S. Kresovich. (2005) "Genetic diversity of Striga hermonthica and Striga asiatica populations in Kenya." Weed Research, 45, 64-73.

Goldsmith, P.D. (2017). The Faustian Bargain of commercial crop agriculture in Africa." Tropical Conservation Science, 10,1-4.

Goldsmith P. and K. Montesdeoca (2018) "The productivity of tropical grain production." International Journal of Agricultural Management, 6, 90-99.

Harashima, A. (2007) "Maize and Grace: Africa's Encounter with a New World Crop, 1500-2000 - By James C. McCann” The Developing Economies, 45, 242-245.

Hardke, J.T., G.M. Lorenz, III, B.R. Leonard. (2015) "Fall Armyworm (Lepidoptera: Noctuidae) Ecology in Southeastern Cotton.” Journal of Integrated Pest Management, 6: 10 .

Harris, D. and A. Orr. (2014) "Is rainfed agriculture really a pathway from poverty?" Agricultural Systems, 123, 84-96.

Hillocks, R.J. (2014) "Addressing the yield gap in Sub-Saharan Africa." Outlook on Agriculture, 43, 85-90.

Irz, X., and R. Tiffin (2006). "Is Agriculture the Engine of Growth?" Agricultural Economics Journal, 35, 79-89.

Jemo, M., R.C. Abaidoo, C. Nolte, M. Tchienkoua, N. Sanginga, W.J. Horst. (2006) "Phosphorus benefits from grain-legume crops to subsequent maize grown on acid soils of southern Cameroon." Plant and Soil, 284, 385- 397.

Kanampiu, F., D Makumbi, E. Magento, G. Omanya, S. Waruingi, P. Musyoka, J. Ransom. (2018) 


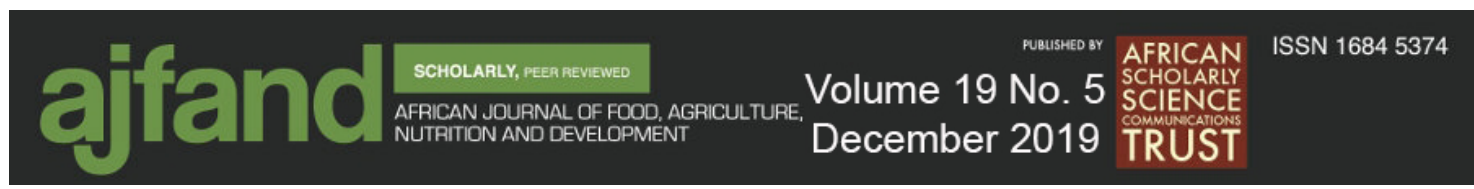

University of Illinois - SIL Farm.Doc Series

"Assessment of Management Options on Striga Infestation and Maize Grain Yield in Kenya." Weed Science, 66, 516-524.

Kawuki, R.S., E. Adipala, J. Lamo, P. Tukamuhabwa. (2003) "Responding to the soybean rust epidemic in sub- Saharan Africa. A Review". Africa Crop Science Journal, $11,301-318$.

Keeton, K. "Malawi's new reality: Fall armyworm is here to stay." International Food Policy Research Institute (IFPRI), February 26, 2018. Web.

Kelley, S. "Depleted soil locks rural farmers in trap of ultra-poverty." Cornell Chronicle - Cornell University, November 23, 2015. Web.

Kermah, M., A.C. Franke, S. Adjei-Nsiah, B.D.K. Ahiabor, R.C. Abaidoo, K.E. Giller. (2018) "N2-fixation and N contribution by grain legumes under different soil fertility status and cropping systems in the Guinea savanna of northern Ghana." Agriculture, Ecosystems and Environment, 261, 201-210.

Khojely D.M., S.E. Ibrahim, E. Sapey, T. Han. (2018) "History, current status, and prospects of soybean production and research in sub-Saharan Africa." The Crop Journal, $6,226-235$.

Kim, S.K., V.O. Adetimirin, C. The, R. Dossou. (2002) "Yield losses in maize due to Striga hermonthica in West and Central Africa." International Journal of Pest Management, 48, 211-217.

Mahuku, G. et al. (2015) "Maize Lethal Necrosis (MLN), an Emerging Threat to MaizeBased Food Security in Sub-Saharan Africa.” Phytopathology, 105, 956-965.

Mango, N., C. Makate, L. Mapemba, M. Sopo. (2017) "The role of crop diversification in improving household food security in central Malawi." Agriculture \& Food Security, 7,7 .

Murithi, H.M., F. Beed, P. Tukamuhabwa, B.P.H.J. Thomma, M.H.A.J. Joosten. (2015) "Soybean production in eastern and southern Africa and threat of yield loss due to soybean rust caused by Phakopsora pachyrhizi." Plant Pathology, 65, 176-188.

Nuruzzaman, N., H. Lambers, M.D.A. Bolland, E.J. Veneklaas. (2005) "Phosphorus benefits of different legume crops to subsequent wheat grown in different soils of Western Australia." Plant and Soil, 271, 175-187.

Nyagumbo, I, S Mkuhani, C. Pisa, D. Kamalongo, D. Dias, M. Mekuria. (2016) "Maize yield effects of conservation agriculture based maize-legume cropping systems in contrastingagro-ecologies of Malawi and Mozambique." Nutrient Cycling in Agroecosystems, 105, 275-290. 


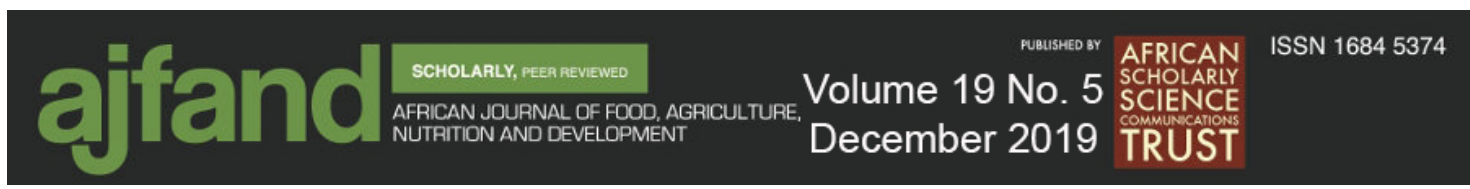

University of Illinois - SIL Farm.Doc Series

Odhiambo, J.A., B. Vanlauwe, I.M. Tabu, F. Kanampiu, Z. Khan. (2011) "Effect of intercropping maize and soybeans on Striga hermonthica parasitism and yield of maize." Archives of Phytopathology and Plant Protection, 44, 158-167.

OECD/FAO (2016) "Chapter 2 - Agriculture in Sub-Saharan Africa: Prospects and challenges for the next decade." OECD-FAO Agricultural Outlook 2016-2025, Special Focus: Sub-Saharan Africa, OECD Publishing, Paris.

Olaniyan, A., E Udo, A, Afolami. (2016) "Performance of soybean (Glycine max L.) influenced by different rates and sources of phosphorus fertilizer in south-west Nigeria." AGROFOR International Journal, 1, 46-51.

Oliveira Duarte, J., J.C. Cruz, J.C. Garcia. (2007) "Evolução da Produção da Milho Safrinha no Estado de Mato Grosso." $9^{\circ}$ Seminário Nacional Milho Safrinha Rumo à Estabilidade. Embrapa Agropecuária Oeste - Comitê de Publicações da Unidade, Mato Grosso do Sul.

One Acre Fund. "2016 Long Rains - Maize-Legume Rotation.” One Acre Fund. 2016. Web.

Pypers, P., M. Huybrighs, J. Diels, R. Abaidoo, E. Smolders, R. Merckx (2007) “Does the enhanced $\mathrm{P}$ acquisition by maize following legumes in a rotation result from improved soil P availability?" Soil Biology and Biochemistry, 39, 2555-2566.

Ravallion, M. and G. Datt. (1999). "When Is Growth Pro-Poor? Evidence from the Diverse Experiences of India's States.” Policy Research Working Paper 2263, World Bank, Washington, DC. Richardson, A.E., P.J. Hocking, R.J. Simpon, T.S. George. (2009) "Plant mechanisms to optimise access to soil phosphorus." Crop and Pasture Science, 60, 124-143.

Rurinda, J., M.T. van Wijk, P. Mapfumo, K. Descheemaeker, I. Supit, K.E. Giller. (2015) "Climate

change and maize yield in southern Africa: what can farm management do?" Global Change Biology, 21, 4588- 4601.

Sinclair, T.R., H Marrou, A. Soltani, V. Vadez, K.C. Chandolu. (2014) "Soybean production potential in Africa."

Global Food Security, 3, 31-40.

Skoufias, E. "All hands on deck: Halting the vicious circle of stunting in Sub-Saharan Africa." World Bank, November 28, 2018. Web.

Sosa-Gómez, D.R. "Chapter 13 - Microbial Control of Soybean Pest Insects and Mites", Ed.: Lawrence A. Lacey, Microbial Control of Insect and Mite Pests, Academic Press, 2017, 199-208, ISBN 9780128035276. 


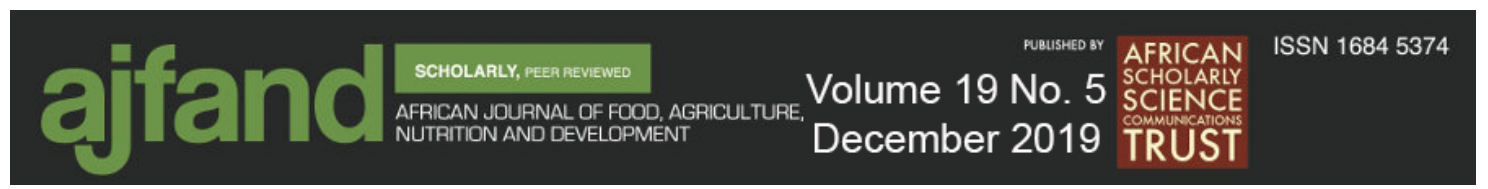

University of Illinois - SIL Farm.Doc Series

Soybean Innovation Lab (SIL). (2019) "How to grow soybean in Ghana." USAID Soybean Innovation Lab. Web. Tadele, Z. (2018) "Raising Crop Productivity in Africa through Intensification." Agronomy, 7, 22.

Ulzen, J. R.C. Baidoo, N. Ewusi-Mensah, C. Masso. (2018) "On-farm evaluation and determination of sources of variability of soybean response to Bradyrhizobium inoculation and phosphorus fertilizer in northern Ghana." Agriculture, Ecosystems \& Environment, 15, 23-32.

UNICEF. "Levels and trends in child malnutrition: key findings of the 2017 edition." UNICEF/WHO/ World Bank Group. 2017. Web.

Uzoh, I.M., C.A. Igwe, C.B. Okebalama, O.O. Babalola (2019) "Legume-maize rotation effect on maize productivity and soil fertility parameters under selected agronomic practices in a sandy loam soil." Scientific Reports, 9, 8539.

van Ittersum, M. K. et al., (2016) "Can sub-Saharan Africa feed itself?” PNAS, 113, 14964-14969.

Zwane, E.M., K.E. Davis. (2017) "Extension and advisory services: the African renaissance." South African Journal of Agricultural Extension, 45, 78-89. 